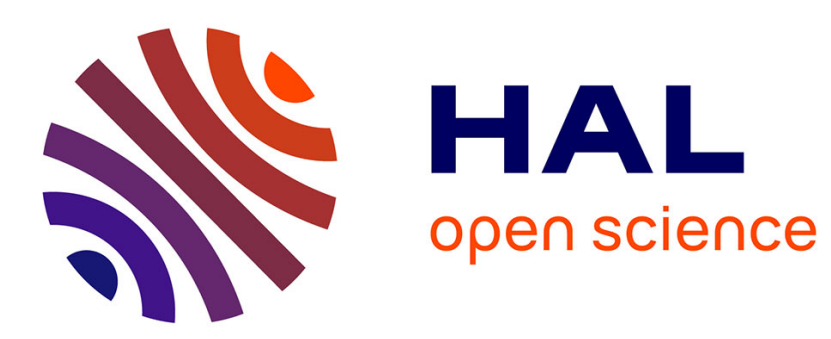

\title{
Global validation of the ISBA sub-grid hydrology
}

Bertrand Decharme, Hervé Douville

\section{To cite this version:}

Bertrand Decharme, Hervé Douville. Global validation of the ISBA sub-grid hydrology. Climate Dynamics, 2007, 29, pp.21-37. meteo-00177865

\section{HAL Id: meteo-00177865}

\section{https://hal-meteofrance.archives-ouvertes.fr/meteo-00177865}

Submitted on 2 Nov 2007

HAL is a multi-disciplinary open access archive for the deposit and dissemination of scientific research documents, whether they are published or not. The documents may come from teaching and research institutions in France or abroad, or from public or private research centers.
L'archive ouverte pluridisciplinaire HAL, est destinée au dépôt et à la diffusion de documents scientifiques de niveau recherche, publiés ou non, émanant des établissements d'enseignement et de recherche français ou étrangers, des laboratoires publics ou privés. 


\title{
Global Validation of the ISBA Sub-Grid Hydrology
}

\author{
B. DECHARME ${ }^{1}$, H. DOUVILLE ${ }^{2}$
}

Corresponding Authors' Address:

(1) CETP-IPSL-CNRS, 10 avenue de l'Europe, 78140 Vélizy-Villacoublay, France

(2) Météo-France, CNRM/GMGEC/UDC, 42 ave. G. Coriolis, 31057 Toulouse, France.

E-mail : bertrand.decharme@cetp.ipsl.fr herve.douville@meteo.fr 


\begin{abstract}
Over recent years, many numerical studies have suggested that the land surface hydrology contributes to atmospheric variability and predictability on a wide range of scales. Conversely, land surface models have been also used to study the hydrological impacts of seasonal climate anomalies and of global warming. Validating these models at the global scale is therefore a crucial task, which requires off-line simulations driven by realistic atmospheric fluxes to avoid the systematic biases commonly found in the atmospheric models. The present study is aimed at validating a new land surface hydrology within the ISBA land surface model. Global simulations are conducted at a $1^{\circ}$ by $1^{\circ}$ horizontal resolution using 3-hourly atmospheric forcings provided by the Global Soil Wetness Project. Compared to the original scheme, the new hydrology includes a comprehensive and consistent set of sub-grid parametrizations in order to account for spatial heterogeneities of topography, vegetation and precipitation within each grid cell. The simulated runoff is converted into river discharge using the TRIP river routing model, and compared with available monthly observations at 80 gauging stations distributed over the world's largest river basins. The simulated discharges are also compared with parallel global simulations from five alternative land surface models. Globally, the new sub-grid hydrology performs better than the original ISBA scheme. Nevertheless, the improvement is not so clear in the high-latitude river basins (i.e. Ob, MacKenzie), which can be explained by a too late snow melt in the ISBA model. Over specific basins (i.e. Parana, Niger), the quality of the simulated discharge is also limited by the TRIP river routing model, which does not account for the occurrence of seasonal floodplains and for their significant impact on the basin-scale water budget.
\end{abstract}




\section{Introduction}

In general, the continental fresh water reservoirs have a strong temporal variability due to their relatively low capacity. This phenomenon can have dramatic consequences for the populations of some regions of the world during seasonal flood or drought events. Subjected to the climatic hazards, these reservoirs also represent an active component of the climate system (Beljaars et al. 1996, Dirmeyer 2000, 2001; Douville et al. 2001; Douville 2002, 2003; Koster et al. 2000a, 2002) and are likely to influence the water and energy exchanges at the land surface, the ocean salinity at the mouth of the largest rivers, and probably the whole climate at least at the regional scale (Gedney et al. 2000; Douville et al. 2000a, b). Nevertheless, the knowledge and understanding of the continental hydrological cycle is still limited by the lack of global observations, even if current progress in remote sensing techniques (Alsdorf and Lettenmaier 2003; Wigneron et al. 2003; Grippa et al. 2004) should improve the situation in the near future. Meanwhile, in situ observations like river discharge and soil moisture remain very useful to understand the evolution of the continental hydrology (Robock et al. 2000). However, soil moisture measurements are very sparse and not sufficient over most regions of the globe.

Besides observations, the understanding of the continental hydrological cycle requires numerical tools making it possible to analyze the mechanisms that control the evolution of the various continental reservoirs, and ultimately to predict this evolution from daily to climate change timescales. Land surface models (LSMs) were introduced in atmospheric general circulation models (AGCMs) to provide realistic lower boundary conditions on temperature and moisture. Their complexity ranges from the simple bucket model (Manabe 1969) to more sophisticated soilvegetation-atmosphere transfer schemes with multiple parameterizations representing the physical processes linked to soil, vegetation, and snow. Their validation is mainly based on off-line simulations due to the large systematic errors that are still commonly found in most atmospheric models. Besides local tests, validation at the basin scale is necessary to evaluate the breakdown of 
precipitation between evaporation, water storage and runoff. For this purpose, river routing models (RRMs) can be used to convert the simulated runoff into river discharge at any gauging stations over a selected river basin and then to validate the water budget simulated over the corresponding drainage area by comparing simulated discharges with observations (Habets et al. 1999b; Oki et al. 1999; Ngo-Duc et al. 2005; Decharme and Douville 2006a, b). This strategy is now widely used and represents a powerful tool to detect major deficiencies in the LSMs (Lohmann et al. 1998; Chapelon et al. 2002; Boone et al. 2004; Decharme et al. 2006).

In state-of-the-art AGCMs, the land surface water budget is calculated on grid cells whose side measures typically from 50 to $300 \mathrm{~km}$. At such a resolution, the sub-grid distribution of the atmospheric fluxes and land surface characteristics has a significant impact on the mean water budget simulated within each grid box. In other words, regional and global hydrological simulations are generally sensitive to the horizontal resolution of the computation grid (Dirmeyer et al. 1999; Verant et al. 2004; Boone et al. 2004; Decharme et al. 2006). Nevertheless, this sensitivity can be reduced by introducing sub-grid parameterizations of the main hydrological processes (Dirmeyer et al. 1999; Boone et al. 2004). This remark was recently reinforced by Decharme and Douville (2006a) using the ISBA LSM with a new sub-grid hydrology over the Rhône river basin at both high $(8 \mathrm{~km}$ by $8 \mathrm{~km})$ and low $\left(1^{\circ}\right.$ by $\left.1^{\circ}\right)$ resolution. This parameterization accounts for the sub-grid variability of precipitation, topography, soil maximum infiltration capacity, and vegetation properties. Compared to the original version of ISBA, the new sub-grid hydrology performed much better at both daily and monthly timescales, and was much less sensitive to the spatial aggregation. While very successful over the Rhône river basin, the validation must be extended at the global scale.

The goal of the present study is to evaluate the impact of the new ISBA Sub-Grid Hydrology (ISBA-SGH) in global off-line hydrological simulations over the 1986-1995 period. This global validation is based on discharge scores evaluated over the most important rivers of the globe using 
the TRIP river routing model. An evaluation is also made using a comparison with parallel off-line simulations from five state-of-the-art land surface models. The description of the ISBA LSM, as well as a brief review of the new sub-grid hydrology, is provided in section 2. The global atmospheric forcing, the land surface parameters and the experiment design are described in section 3. The main results are presented in section 4 and discussed in section 5. Finally, the conclusions are provided in section 6 .

\section{ISBA Sub-Grid Hydrology}

\section{a. The initial version of ISBA}

The ISBA LSM (Fig. 1) is a simple land surface model which uses the force-restore method (Deardorff 1977, 1978) and a limited number of parameters to calculate the time evolution of the surface and mean soil temperature (Noilhan and Planton 1989). The water budget is based on a soil hydrology, a simple soil freezing scheme (Boone et al. 2000), a rainfall interception scheme (Mahfouf et al. 1995), and a one-layer simple snow scheme (Douville et al. 1995). ISBA has a three-layer soil hydrology: a thin surface layer included in the rooting layer and a third layer in order to distinguish between the rooting depth and the total soil depth (Boone et al. 1999). The infiltration rate is computed as the difference between the through-fall rate and the surface runoff. The through-fall rate is the sum of the rainfall not intercepted by the canopy, the dripping from the interception reservoir and the snowmelt from the snow pack. The dripping from the canopy is calculated according to Mahfouf et al. (1995) in which precipitation spatial heterogeneities are taken into account by an exponential distribution that depends on both the mean rainfall rate over the grid cell and the fraction of the grid cell, $\mu$, affected by rainfall. This last parameter is assumed constant, uniform and equal to 0.1 over the globe according to Dolman and Gregory (1992). This configuration of the ISBA model correspond to the control version $(C T L)$ tested in this study where surface runoff only occurs when the soil moisture is higher than the soil porosity. 
In the second version of ISBA tested here, the surface runoff over saturated area, named Dunne runoff, is added and computed using the Variable Infiltration Capacity (VIC) scheme (Zhao 1977; Dümenil and Todini 1992; Wood et al. 1992; Habets et al. 1999a). The saturated fraction of the grid cell computed by the VIC scheme depends on soil moisture, precipitation intensity and a shape parameter, $B$. As in Dümenil and Todini (1992), $B$ is computed using the standard deviation of orography, $\sigma_{h}$, in each grid cell at the considered model resolution ( $1^{\circ}$ in this study):

$$
B=\max \left(\frac{\sigma_{h}-\sigma_{h, \min }}{\sigma_{h}+\sigma_{h, \max }}, 0.1\right)
$$

where $\sigma_{h, \min }$ and $\sigma_{h, \max }$ are the minimum and maximum standard deviation of orography over the globe. The total runoff is the sum of surface runoff and the deep drainage. This deep drainage is the sum of the gravitational drainage (Mahfouf and Noilhan 1996) and a linear residual drainage when the soil moisture of each layer is below the field capacity. The idea is to take into account the spatial heterogeneity of soil moisture and soil hydraulic properties within a grid box (Habets et al. 1999b; Etchevers et al. 2001). This linear residual drainage is not calibrated basin by basin and depends to a coefficient assumed constant and uniform over the globe. This version of ISBA is named $d t 92$ by reference to the calibration of the $B$ parameter (eq. 1) proposed by Dümenil and Todini (1992).

\section{b. Review of the new ISBA sub-grid hydrology}

First, the Dunne runoff is computed using a new TOPMODEL approach (Habets and Saulnier 2001) instead of the VIC scheme. This version is simply named Top. TOPMODEL attempted to combine the important distributed effects of channel network topology and dynamic contributing areas for runoff generation (Beven and Kirkby 1979; Sivapalan at al. 1987). This formalism takes into account topographic heterogeneities explicitly by using the spatial distribution of the topographic indices, $\lambda_{i}(\mathrm{~m})$, in each grid-cell defined as follows:

$\lambda_{i}=\ln \left(a_{i} / \tan \beta_{i}\right)$ 
where $a_{i}(\mathrm{~m})$ is the drainage area per unit of contour of a local pixel, $i$, and $\tan \beta_{i}$ approximates the local hydraulic gradient where $\beta_{i}$ is the local surface slope. If the pixel has a large drainage area and a low local slope, its topographic index will be large and thus, its ability to be saturated will be high. Then, this topographic index can be related to a local water deficit, and using the spatial distribution of the topographic indices over the grid cell, a saturated fraction, $f_{\text {sat }}$, inversely proportional to the grid cell mean deficit can be defined. The Dunne runoff, $Q_{D}$, is thus simply given by: $Q_{D}=P_{g} \times f_{\text {sat }}$ where $P_{g}$ is the throughfall rate. With this formalism, the soil column assumes an exponential profile of the saturated hydraulic conductivity, $k_{s a t}$, with soil depth. This parameterization depends only on two parameters, which represent the rate of decline of the $k_{s a t}$ profile and the depth where $k_{\text {sat }}$ reaches its so-called "compacted value". The first parameter is related to soil properties (relation 11 in Decharme et al. 2006) but can not exceed $2 \mathrm{~m}^{-1}$, and the second is assumed to be equal to the rooting depth. Sensitivity tests to these parameters and a detailed discussion about these parameterizations can be found in Decharme et al. (2006).

Secondly, the sub-grid exponential distribution of rainfall is generalized to the surface runoff of ISBA according to Entekhabi and Eagleson (1989). In addition, this approach is coupled with a sub-grid exponential distribution of the soil maximum infiltration capacity in order to enable the infiltration excess runoff mechanism, named Horton runoff, more realistically. The $\mu$ parameter is computed using the model resolution and the rainfall intensity according to Fan et al. (1996) and Peters-Lidard et al. (1997). Furthermore, this parameterization depends on two maximum infiltration capacity functions proportional to the liquid water and ice content of the soil that enable the Horton runoff to be represented explicitly over unfrozen and frozen soil (Decharme and Douville 2006a). So, this version where the Horton process is added to the Dunne runoff is named Top-Hort.

Lastly, land cover and soil depth heterogeneities are represented using a so-called "tile approach" in which each grid cell is divided into a series of sub-grid patches (Koster and Suarez 
1992; Liang and al. 1994; Essery and al. 2003). This method has the advantage of explicitly representing very distinct surface types with specific properties. Indeed, each sub-grid patch extends vertically throughout the soil-vegetation-snow column. One rooting depth and one soil depth are assigned to each surface class, and distinct energy and water budgets for each tile within a grid box are computed. The relative fractional coverage of each surface type within each grid box is used to determine the grid box average of the water and energy budgets. In consequence, the last version of ISBA (Top-Hort-Tiles) tested in this study takes into account all these sub-grid parameterizations.

\section{Experiment design}

\section{a. Atmospheric forcing and land surface parameters}

All simulations are implemented in off-line mode. The global meteorological forcing is provided by the Global Soil Wetness Project phase 2 (GSWP-2; http://www.iges.org/gswp/) over more than 13 years (July 1982 to December 1995), on 3-hourly time step and at $1^{\circ}$ resolution. GSWP-2 is an international initiative aimed at producing global data sets of soil wetness and energy and water fluxes by driving land surface models with state-of-the-art $1^{\circ}$ by $1^{\circ}$ atmospheric forcing and land surface parameters (Dirmeyer et al. 1999, 2002). It also provides a unique opportunity to develop and test land surface parameterizations at the global scale, using multi-year off-line simulations that are not affected by the systematic errors found in atmospheric models. The GSWP2 atmospheric forcing is based on the International Satellite Land Surface Climatology Project (ISLSCP) initiative II regridded National Centers for Environmental Prediction / Department of Energy (NCEP/DOE) reanalysis. Corrections to the systematic biases in the 3-hourly reanalysis fields are made by hybridization with global observed monthly climatologies. The precipitation is a hybrid product of reanalysis and observations in which GSWP-2 uses NCEP/DOE combined with

Global Precipitation Climatology Centre (GPCC) gauge data for the validation period (1986-1995) and Climatic Research Unit (CRU) data for the spin-up period (1982-1985) when GPCC data is not 
available. Further details and/or additional informations can be found in Zhao and Dirmeyer (2003) and Dirmeyer et al. (2006).

The land surface parameters are specified according to the high resolution ECOCLIMAP data base of Météo-France (Masson et al. 2003). ECOCLIMAP is the data base included in the climatic model of Météo-France. The soil textural properties are given by the Food and Agricultural Organization (FAO) map at $10 \mathrm{~km}$ resolution. Vegetation parameters are defined using two vegetation maps from the Corine Land Cover Archive at 250m resolution over Europe and from the University of Maryland elsewhere at $1 \mathrm{~km}$ resolution. There are 12 distinct surface types considered, and the relative fractional coverage of each surface type within each grid box was used to determine average values for the $1^{\circ}$ by $1^{\circ}$ grid boxes when the tile approach is not used. The topographic indices are available at a $1 \mathrm{~km}$ resolution using the HYDRO1K dataset (http://edcdaac.usgs.gov /gtopo30/hydro). The spatial distribution of the topographic indices in each grid-cell is derived from the mean, standard deviation, and skewness of the actual distribution using a three-parameter gamma distribution (Sivapalan et al. 1987).

\section{b. Experiments}

First, each sub-grid parameterization is evaluated. ISBA is integrated with a 5 min time step for the whole GSWP-2 period. All simulations start from initial condition of soil temperature based on the mean June air temperature, soil moisture at $75 \%$ of saturation, and no snow cover over icefree points. Spin-up is performed using forcing data beginning 1 July 1982 and ending 31 December 1985 and the period 1986 to 1995 is used as the validation stage. To sum up, one control and four simulations with sub-grid parameterizations are performed:

- CTL: ISBA is implemented as in the AGCM of Météo-France (ARPEGE) without deep residual drainage and sub-grid hydrology (except for the dripping). So, surface runoff only occurs when the soil moisture is higher than the soil porosity and only gravitational drainage is taken into account. 
- dt92: This simulation is similar to $C T L$ but includes the sub-grid residual drainage and the Dunne runoff using the VIC scheme with the dt92 calibration (eq. 1).

- Top: The VIC scheme is replaced by TOPMODEL including the exponential profile of $k_{s a t}$. Only the sub-grid variability of topography is taken into account and the Horton runoff is not considered.

- Top-Hort: The Horton process is added to the Dunne runoff. Thus, the $\mu$ parameter varies spatially and surface heterogeneities in maximum infiltration capacity over unfrozen and frozen soil are added.

- Top-Hort-Tiles: All sources of sub-grid variability related to topography, precipitation, maximum infiltration capacity and land surface characteristics are considered.

Secondly, a multi-model comparison is made in order to evaluate the new ISBA Sub-Grid Hydrology which takes into account all sub-grid parameterizations. Indeed, ISBA-SGH is compared to five other state-of-the-art LSMs which have participated in the GSWP2 intercomparison project (Table 1). The water budget simulated by these models has been retrieved from the GSWP2 database. All LSMs considered are at least "second-generation" model because they take into account the effect of vegetation and snow on surface hydrology and include realistic treatments of the surface energy balance. Furthermore, they take into consideration surface runoff and deep drainage mechanisms in order to produce a "realistic" total runoff, and use specific parameterizations to represent the sub-grid hydrology (Table 1). A last experiment, named ISBASGH', is done in order to investigate the importance of the snow pack simulation in the ISBA global hydrological simulations. The baseline 1-layer snow scheme, which uses a composite snowsoil-vegetation energy budget, is replaced by the more detailed multi-layer snow model of Boone and Etchevers (2001). This scheme uses an independent snow energy budget and describes the vertical profile of snow mass, density, liquid water content, and heat content. 


\section{c. Validation strategy}

The Total Runoff Integrating Pathways (TRIP) river routing model (Oki and Sud 1998) is used to convert the daily total runoff simulated by ISBA and the others models into river discharge. Then the simulated water budget can be validated using direct comparison between simulated and observed discharges. TRIP was already used at the global scale by Oki et al. (1999) and Decharme and Douville (2006b) in order to route the runoff produced by several LSMs. The goal of such studies was to quantify the impact of the quality of the meteorological forcing on the simulated water budget. TRIP is a simple linear model based on a single prognostic equation for the water mass within each grid cell of the hydrological network. The stream flow velocity is assumed constant and uniform at $0.5 \mathrm{~m} / \mathrm{s}$. The global river channel network is provided at $1^{\circ}$ resolution (Fig. 1) and adapted to GSWP-2 land-sea mask.

Over the validation period (1986-1995), the Global Runoff Data Center (GRDC; http://www.grdc.sr.unh.edu/index.html), the R-ArticNet database (New Hampshire University; http://www.r-arcticnet.sr.unh.edu/v3.0/index.html) for high latitude basins and the HyBAm dataset (http://www.mpl.ird.fr/hybam/) for the Rio-Amazonas basin give access to more than a hundred gauging station measurements. Nevertheless, the set of monthly streamflow data used for the validation contains no more than 80 river gauges because only sub-basins with drainage areas of at least $10^{5} \mathrm{~km}^{2}$ (Fig. 2) and with a minimum observed period of four years are used (Table 2).

In addition to the evaluation of the simulated discharges, the snow cover extent simulated by each model is validated against satellite observations from the National Snow and Ice Data Center (NSIDC; http://nsidc.org/). This snow cover product is provided by ISLSCP-II over the whole 1986-1995 period, at a monthly time scale, and at $1^{\circ}$ by $1^{\circ}$ horizontal resolution. 


\section{Results}

\section{a. Validation of the new Sub-Grid Hydrology}

Fig. 3 compares the $10-\mathrm{yr}$ mean total runoff ratio to total precipitation, $R$, simulated by each version of ISBA. A significant difference appears between the runoff ratio simulated by $C T L$ and $d t 92$. The inclusion of the Dunne runoff, using the VIC scheme, and of the linear residual drainage leads to an increase in total runoff, except over the Amazon basin where the soil is generally wet and the gravitational drainage is the dominant process. Over arid areas, this increase is partly due to the linear residual drainage that enables runoff to be produce even if soil moisture is very low, whereas the Dunne runoff dominates elsewhere. When the VIC scheme is replaced by TOPMODEL $\left(R_{T o p}-R_{d t 92}\right)$, the total runoff is generally increased over vegetated areas. This increase is due to TOPMODEL, which increases the Dunne runoff compared to VIC, and to the exponential profile of $k_{\text {sat }}$, which favors the deep drainage (Decharme at al. 2006). Over dry area, the exponential profile of $k_{s a t}$ is the main reason for the decrease in total runoff because it favours water storage in the deep reservoir. The Top-Hort simulation reveals that the inclusion of the Horton runoff induces an important increase in total runoff over high-latitude areas. This result is related to the representation of the Horton runoff over frozen soil, which is dominant during the snow melt period. Over the equatorial regions, the small decrease in total runoff is due to the value of the $\mu$ parameter that is generally larger than to 0.1 which then limits the dripping from the canopy reservoir compared to the previous simulations in which $\mu$ is fixed at 0.1 . Lastly, the introduction of the land cover tiles (Top-Hort-Tiles) globally increases the total runoff.

Fig. 4 compares the simulated and observed discharges over the Mississippi, the Amazon and the $\mathrm{Ob}$ river basins. The annual cycles, as well as the monthly anomalies calculated over the whole observation period (Table 2), are represented. The annual runoff simulated by each model version is evaluated using the annual discharge ratio criterion $\left(\overline{Q_{\text {sim }}} / \overline{Q_{o b s}}\right)$, whereas the efficiency, 
Eff, criterion (Nash and Sutcliffe 1970) measures the model ability to capture the monthly discharge dynamics. This skill score is defined as follows:

$$
E f f=1.0-\frac{\sum\left(Q_{\text {sim }}(t)-Q_{o b s}(t)\right)^{2}}{\sum\left(Q_{\text {obs }}(t)-\overline{Q_{o b s}}\right)^{2}}
$$

where $\overline{Q_{o b s}}$ represents the observed temporal mean. Eff can be negative if the simulated discharge is very poor, is above 0.5 for a reasonable simulation, above 0.7 for a good one and 1 for a perfect model (Boone et al. 2004). The quality of the simulated anomalies is evaluated using the square correlation criterion $\left(r^{2}\right)$. Over the Mississippi basin, the introduction of the Dunne runoff and of the linear residual drainage ( $d t 92$ or Top compared to $C T L$ ) improves the annual cycle as well as the annual discharge ratio between simulated and observed discharges. The efficiency criterion shows that the monthly discharge dynamics is also improved. This result is confirmed by the correlations between simulated and observed anomalies, which give an advantage to TOPMODEL compared to the VIC scheme. The introduction of the Horton runoff improves the Mississippi discharge simulations in many respects. This is mainly due to the parameterization of the surface runoff over frozen soil which increases the simulated runoff during winter and spring whereas the Horton runoff over unfrozen soil has a more important effect during summer. Nevertheless, the most important enhancement is linked to the tiles approach that permits significant improvement of all discharge scores. Over the Amazon basin, the efficiency criterion shows that both TOPMODEL and the exponential profile of $k_{s a t}$ improve the quality of the simulated discharges. Nevertheless, the square correlations of the simulated discharge anomalies are slightly reduced due to a little shift from the observations. The introduction of the Horton runoff has just a weak impact on the discharge simulations due to the basin characteristics that favor surface infiltration, water storage and deep soil percolation (Delire et al. 1997). Moreover, as already said, the value of the $\mu$ parameters leads to a slight decrease in the annual discharge ratio. The effect of the tiles is less significant than over the Mississippi basin but significantly improves the efficiency criterion. Over 
the $\mathrm{Ob}$ basin, TOPMODEL improves the discharge scores compared to the VIC. At these high latitudes, the dominant effect is however linked to the representation of surface runoff over frozen soil explicitly included in the Horton process parameterization. Accordingly, the introduction of the Horton runoff leads to a drastic improvement of all statistical criteria and thus of the hydrological simulations. The impact of the land cover heterogeneities is more questionable even if the annual discharge ratio is clearly improved. Indeed, the tiles approach increases the total runoff but does not improve the discharge efficiency due to a shift in the springtime peak of discharge.

In addition, Fig. 5 provides a global synthesis of the discharge scores calculated at 80 gauging stations distributed over world's largest river basins (Fig. 2). Fig. 5a shows that all sub-grid parameterizations contribute to improve the annual ratio of simulated to observed discharges. The introduction of the tiles is the most important contribution. The cumulative distribution of efficiencies (Fig. 5b) confirms that the quality of the simulated monthly discharges is also significantly improved by each parameterization. Fig. 6 gives an overview of the regional performance of each parameterization. The introduction of the Dunne runoff using the VIC scheme and of the residual linear drainage improves the efficiency over the majority of the regions selected in Fig. 2. Globally, Fig. 5 and 6 confirm that TOPMODEL shows a clear advantage compared to the more empirical VIC scheme. In addition, these figures emphasize the importance of the Horton runoff over frozen soil that allows us to improve the discharge simulations over the mid-and-high northern latitude basins. The representation of land cover heterogeneities also plays a significant role in this general improvement, especially over Europe, North America and the Amazonian region. Note that discharge scores over the African basins and over the Parana and the SaoFrancisco Rivers (South America) are very poor for each model version. This feature will be further discussed in the following section. 


\section{b. Multi-model comparison}

In this section, the results of ISBA-SGH are evaluated against simulations from other LSMs. Fig. 7 shows that ISBA-SGH is not only better than the initial version of ISBA (dt92), but also provides better discharge scores over the Mississippi, the Danube, the Amazon and the Ob basins (in terms of annual discharge ratio and monthly efficiency) than the other LSMs, which was not the case with $d t 92$. Note that over the Danube basin, only NSIPP shows a better efficiency than ISBASGH even if the simulated discharge is clearly underestimated. As far as interannual variability is concerned, the model physics has a less significant impact on the monthly discharge anomalies (not shown), even if the implementation of a sub-grid hydrology generally improves the quality of the ISBA simulation. This remark is consistent with the soil moisture outputs of GSWP showing that the model spread is much stronger for the mean soil water content than for its interannual variability (Entin et al. 1999). Moreover, the simple comparison of the cumulated efficiency distributions of the monthly river discharges derived from all LSMs (Fig. 8) confirms that ISBA-SGH globally provides more realistic discharge simulations than the other models. Yet, ISBA-SGH is not the only model that includes sub-grid hydrological parameterizations (Table 1). Its advantage can be explained by the use of a relatively comprehensive and consistent set of parameterizations that have been already carefully tested at the regional scale (Decharme and Douville 2006a). Looking at the spatial distributions of the efficiency over the globe (Fig. 9), this advantage is more obvious over North America, South Asia and Amazonia than over Siberia. Another important result is that Fig. 9 shows that the significant overestimation by all models of the discharge of some tropical rivers like the Parana and the Niger (Fig. 7) induces poor efficiencies.

Besides these tropical regions, our results suggest that the main limitation of ISBA-SGH is partly due to the empirical parameterization of cold processes over the northern high-latitude basins. Indeed, Fig. 10 shows that the annual maximum of monthly discharges over the $\mathrm{Ob}$ and Mackenzie basins simulated by ISBA-SGH are not in phase with the observations and show a delay of about 1 
month. This is clearly related to the snow melt simulation that also shows an important delay compared to the satellite observations. Conversely, the other LSMs show a relatively better simulation of the snow melt and, consistently, a more realistic simulation of the springtime peak of discharge. Nevertheless, the implementation of a more physical snow scheme in the ISBA-SGH' simulation clearly improves both the snow pack and discharge simulations.

\section{Discussion}

The results of this study point out that the parameterizations of sub-grid hydrological processes can clearly improve global hydrological simulations based on the ISBA land surface model. The representation of land cover heterogeneities using a tiles approach leads to a significant improvement of the simulated annual discharges because total runoff is globally increased. Indeed, heterogeneities in land cover and soil properties tend to reduce plant's transpiration (Decharme and Douville 2006a). So, water storage is favoured to the detriment of evapotranspiration and then, total runoff is generally more important after a rainfall event.

An important result is that the TOPMODEL formalism globally improves discharge scores compared to the more empirical VIC scheme, whereas most previous regional studies (Habets and Saulnier 2001; Warrach et al. 2002; Decharme and Douville 2006a) suggested that both parameterizations were equivalent in terms of runoff production. Nevertheless, at the global scale, TOPMODEL improves most discharge scores compared to VIC due to an enhancement of the Dunne runoff. Indeed, the mathematical relationship between soil moisture and the saturated fraction in each grid cell is more realistically represented using the topography explicitly than using a shape parameter that is fixed or empirically linked to the orography (Eq. 1). So, TOPMODEL has two main advantages: it takes into account topographic heterogeneities explicitly and its formulation does not depend on any calibration. Indeed, the ISBA-TOPMODEL parameters only depend on soil properties (Decharme et al. 2006) and on the effective distribution of the topography while the global distribution of the VIC shape parameter is still poorly known and generally needs a 
calibration in regional applications. The exponential profile of $k_{s a t}$ also improves the quality of the simulated discharges, especially over basins like the Amazon, the Mississippi or the Mekong River. Elsewhere, its influence is less significant. Over the Rhône basin, Decharme et al. (2006) and Decharme and Douville (2006a) have shown that this parameterization had a positive impact on the simulated daily discharges. In the present study, daily discharge measurements are not available and the validation is limited to the monthly time scale, which might partly explain the weaker impact found on the efficiency criterion. Moreover, former sensitivity studies of the exponential profile parameters (Decharme et al. 2006) revealed that the impact of the exponential profile of $k_{s a t}$ is sensitive to the prescribed soil parameters whose quality is not established at the global scale.

The sub-grid variability of rainfall, simply coupled with the spatial heterogeneity in maximum infiltration capacity, permits calculation of the Horton runoff. Its introduction within ISBA has a significant influence on the simulations over the mid-and-high latitude basins. Indeed, this study point outs that the specific treatment of the Horton runoff over frozen soil significantly improves the quality of the simulated discharges over these regions. This process is dominant during the snow melt period and therefore requires a realistic simulation of the snow pack. Nevertheless, this study shows that the main limitation of ISBA-SGH is probably related to the empirical representation of cold processes. Over the high-latitude basins, the monthly discharges simulated by ISBA-SGH and TRIP are not in phase with the observations. This problem is clearly due to a delayed snow melt in the ISBA simulations and may be solved by the use of a more physical snow scheme proposed by Boone and Etchevers (2001).

While ISBA-SGH improves the general quality of the simulated discharges compared to the former version of ISBA, the multi-model intercomparison reveals that only 20 to $40 \%$ of the gauging stations simulated by all LSMs show an acceptable efficiency (Eff>0.5). Besides uncertainties related to the LSM parameterizations or to the possible anthropic influence on the observed discharge (difficult to quantify), the major difficulty in the validation of regional or global 
hydrological simulations is related to the quality of the atmospheric forcing. Indeed, the GSWP-2 atmospheric forcing is certainly not perfect (Decharme and Douville 2006b) and this is a significant limitation for the quality of the simulated discharges (Oki et al. 1999; Chapelon et al. 2002; NgoDuc et al. 2005; Decharme and Douville 2006b). Uncertainties in the precipitation forcing are generally translated to at least the same and typically much greater uncertainties in total runoff (Fekete et al. 2003). Moreover, some problems are certainly related to the TRIP river routing model used to convert runoff into discharge. Fig. 10 reveals that a good simulation of snow melt by each LSM over the Mackenzie River basin does not necessarily implies a realistic simulation of the springtime peak of discharge, which is then delayed by 1 month. This delay might be due to the fact that TRIP uses a constant and uniform stream flow velocity. Arora and Boer (1999) have shown that, when the stream flow velocity depends on the water mass stored in the hydrological network, the flow can be faster than the constant value used in TRIP over the high-latitude regions during the snow melt period. The introduction of such a parameterization in TRIP could therefore allow the improvement of the global hydrological simulations. In addition, over some tropical region like the Parana or the Niger River basin, the main problem is the existence of seasonal floodplains, which tend to smooth the annual cycle of downstream discharges but are difficult to simulate with a coarse land surface model. Nevertheless, Ngo-Duc et al. (2005) have shown, using a simple floodplain scheme within the ORCHIDEE LSM, some encouraging results over the Parana River. Moreover, besides the improvement of the simulated discharges, such a parameterization could lead to a more realistic simulation of the surface water and energy budgets by accounting for the direct evaporation from the flooded fraction of the grid cell and for a possible re-infiltration into the soil. Because these seasonal floodplains cover a significant fraction of the globe (Prigent et al. 2001), their representation within LSMs also appears as an important prospect for the future. 


\section{Conclusion}

This study shows the impact of various parameterizations of sub-grid hydrological processes on global hydrological simulations based on the ISBA LSM. These parameterizations account explicitly for the sub-grid variability of topography, precipitation, maximum infiltration capacity, and land surface properties. All simulations are performed at a $1^{\circ}$ by $1^{\circ}$ resolution, using the atmospheric forcing provided by GSWP-2 and the ECOCLIMAP land surface data base. The ISBA runoff is converted into river discharge using the TRIP river routing model, and validated against a dense network of gauging stations over the most important basins of the world.

All results show that the representation of sub-grid variability in the ISBA LSM drastically improves the global hydrological simulations. The representation of land cover heterogeneities and the introduction of the Dunne and Horton (especially over frozen soil) runoff are clearly recommended for realistic discharge simulations over the world's largest river basins. The Dunne runoff appears as particularly important. The use of a TOPMODEL formalism, which accounts explicitly for the strong effect of the topography on soil moisture heterogeneities and thus on runoff production, is strongly recommended. The introduction of the Horton runoff, using a statisticaldynamical representation of the sub-grid variability of precipitation and maximum infiltration capacity, is also recommended, especially over mid-and-high latitude river basins where the infiltration excess mechanism over frozen soil is a major process. Lastly, the explicit use of heterogeneous land surface properties, though the tiles approach, leads to an increase in the total runoff simulated by ISBA. This increase in annual discharge is generally associated with a better simulation of the discharge dynamics at the seasonal to interannual timescales.

A comparison with other global hydrological simulations from five alternative LSMs, which represents a broad spectrum of the state-of-the-art models in use today, confirms that, while the original version of the ISBA model was in the middle of the model distribution as far as the discharge efficiencies are concerned, the new formulation performs better than any other model 
available in the GSWP-2 data base. This encouraging result confirms the good behaviour of ISBASGH over the Rhône river basin (Decharme and Douville 2006a), and emphasizes the need for a relatively comprehensive set of sub-grid parameterizations for realistic global hydrological simulations without any basin-scale calibration.

Nevertheless, this study also points out some deficiencies in our global hydrological simulations. The first one is related to the representation of the snow pack, and can be solved by the use of a more physical snow scheme. This result emphasizes the relevance of the parameterization of cold processes for global hydrological simulations. Over tropical rivers like the Parana or the Niger basin, our hydrological simulations are penalized by the lack of seasonal floodplains in both ISBA and TRIP. The parameterization of these floodplains through a genuine coupling between ISBA and TRIP appears therefore as an important task for the near future. Preliminary developments have been tested and have already improved several aspects of our global hydrological simulations. They will be the focus of a forthcoming study.

\section{Acknowledgments}

The authors would like to thank all their colleagues at Météo-France/CNRM that have participated in the development of this study. Thanks are also due to A. Boone for his useful comments on the multi-layer snow scheme as well as to anonymous reviewers for their constructive comments. Finally, we wish to thank P.-E. Decharme for his supports. This work was supported by Météo-France/CNRM and by the ACI "Observation de la Terre" of the French Research Ministry. 


\section{REFERENCES}

Alsdorf DE, Lettenmaier DP (2003) Tracking fresh water from space. Science 301: 1485-1488.

Arora VK, Boer GJ (1999) A variable velocity flow routing algorithm for GCMs. J Geophy Res 104: 30965-30979.

Beljaars ACM, Viterbo P, M.J. Miller (1996) The anomalous rainfall over the united states during july 1993: Sensitivity to land surface parametrization and soil moisture anomalies. Mon Wea Rev 124: 739-805.

Beven KJ, Kirkby MJ (1979) A physically-based variable contributing area model of basin hydrology, Hydrol Sci Bull 24: 43-69.

Boone A et al (2004) The Rhône-Aggregation land surface scheme intercomparison project: An overview. J Climate 17: 187-208.

Boone A, Etchevers P (2001) An intercomparaison of three snow scheme of varying complexity coupled to the same land surface model : local-scale evaluation at an alpine site. J Hydrometeor 2: $374-394$.

Boone A, Calvet JC, Noilhan J (1999) Inclusion of a third soil layer in a land surface scheme using the force-restore method. J Appl Meteor 38: 1611-1630.

Boone A, Masson V, Meyers T, Noilhan J (2000) The influence of the inclusion of soil freezing on simulation by a soil-atmosphere-transfer scheme. J Appl Meteor 9: 1544-1569.

Chapelon N, Douville H, Kosuth P, Oki T (2002) Off-line simulation of the Amazon water balance : a sensitivity study with implications for GSWP. Climate Dyn 19: 141-154.

Deardorff JW (1977) A parametrization of ground-surface moisture content for use in atmospheric prediction model. J Appl Meteor 16: 1182-1185.

Deardorff JW (1978) Efficient prediction of ground surface temperature and moisture with inclusion of a layer of vegetation. J Geophys Res 20: 1889-1903.

Decharme B, Douville H (2006a) Introduction of a sub-grid hydrology in the ISBA land surface model. Climate Dyn 26: 65-78.

Decharme B, Douville H (2006b) Uncertainties in the GSWP-2 precipitation forcing and their impacts on regional and global hydrological simulations. Climate Dyn 27: 695-713. 
Decharme B, Douville H, Boone A, Habets F, Noilhan J (2006) Impact of an exponential profile of saturated hydraulic conductivity within the ISBA LSM: simulations over the Rhône basin. J Hydrometeor 7: 61-80.

Delire C, Calvet JC, Noilhan J, Wright I, Manzi A, Nobre C (1997) Physical properties of Amazonian soils: A modeling study using the Anglo-Brazilian Amazonian Climate Observation Study data. J Geophys Res 102: 30119-30113.

Dirmeyer PA (2000) Using a global soil wetness dataset to improve seasonal climate simulation. J Climate 13: 2900-2922.

Dirmeyer PA (2001) An evaluation of the strength of land-atmosphere coupling. J Hydrometeor 2: 329-344.

Dirmeyer PA, Dolman AJ, Sato N (1999) The Global Soil Wetness Project : A pilot project for global land surface modeling and validation. Bull Amer Meteor Soc 80: 851-878.

Dirmeyer PA, Zeng FJ (1999) Precipitation infiltration in the Simplified SiB Land Surface Scheme. J Meteor Soc Japan 77: 291-303.

Dirmeyer PA, Gao X, Oki T (2002) The Second Global Soil Wetness Project GSWP2: Science and Implementation Plan. IGPO publication Series 37, 65 pp, International GEWEX Project Office.

Dirmeyer PA, Gao X, Zhao M, Guo Z, Oki T, Hanasaki N (2006) The Second Global Soil Wetness Project (GSWP-2): Multi-model analysis and implications for our perception of the land surface. Bull. Amer Meteor Soc, in press.

Dolmant AJ, Gregory D (1992) A parameterization of rainfall interception in GCMs. Quart J Roy Meteor Soc 118: 455-467.

Douville H (2002) Influence of soil moisture on the Asian and African monsoons. Part II: Interannual variability. J Climate 15: 701-720.

Douville H (2003) Assessing the influence of soil moisture on seasonal climate variability with AGCMs. J Hydrometeor 4: 1044-1066.

Douville H, Royer JF, Mahfouf JF (1995) A new snow parameterization for the Météo-France climate model. Part I: validation in stand-alone experiments. Climate Dyn 12: 21-35.

Douville H, Planton S, Royer JF, Stephenson DB, Tyteca S, Kergoat L, Lafont S, Betts RA (2000a) Importance of vegetation feedbacks in doubled-CO2 time-slice experiments. J Geophys Res 105: 14841-14861. 
Douville H, Royer JF, Polcher J, Cox P, Gedney N, Stephenson DB, Valdes P (2000b) Impact of $\mathrm{CO} 2$ doubling on the Asian summer monsoon: robust versus model-dependent responses. J Meteor Soc Japan 78: 421-439.

Douville H, Chauvin F, Broqua H (2001) Influence of soil moisture on the Asian and African monsoons. Part I: Mean monsoon and daily precipitation. J Climate 14: 2381-2403.

Ducharne A, Koster DR, Suarez MJ, Stieglitz M, Kumar P (2000) A catchement-based approach to modeling land surface process in a general circulation model: 2. Parameter estimation and model demonstration. J Geophys Res 105: 24 823-24 838.

Dümenil L, Todini E (1992) A rainfall-runoff scheme for use in the Hamburg climate model. Adv Theor Hydrol 9: 129-157.

Ek MB, Mitchell KE, Lin Y, Grunmann P, Rogers E, Gayno G, Koren V, Tarpley JD (2003) Implementation of the upgraded Noah land-surface model in the NCEP operational mesoscale Eta model. J Geophys Res 108, 8851, doi:10.1029/2002JD003296.

Entekhabi D, Eagleson PS (1989) Land surface hydrology parameterization for atmospheric general circulation models including subgrid spatial variability. J climate 2: 816-831.

Entin JK, Robock A, Vinnikov KY, Zabelin V, Liu S, Namkhai A (1999) Evaluation of Global Soil Wetness Project soil moisture simulations. J Meteor Soc Japan 77: 183-198.

Essery RL, Best MJ, Betts A, Cox PM, Taylor CM (2003) Explicit representation of subgrid heterogeneity in a GCM land surface scheme. J Hydrometeor 4: 530-543.

Etchevers P, Colaz C, Habets F (2001) Simulation of the water budget and the rivers flows of the Rhône basin from 1981 to 1994. J Hydrol 244: 60-85.

Fan Y, Wood EF, Baeck ML, Smith JA (1996) The fractional coverage of rainfall over a grid: Analyses of NEXRAD data over the southern plains. Water Resour Res 32: 2787-2802.

Fekete BM, Vörösmarty CJ, Road JO, Willmott CJ (2003) Uncertainties in Precipitation and their impacts on runoff estimates. J Climate 17: 294-304.

Gedney N, Cox PM (2003) The sensitivity of global climate model simulations to the representation of soil moisture heterogeneity. J Hydrometeor 4: 1265-1275.

Gedney N, Cox PM, Douville H, Polcher J, Valdes PJ (2000) Characterising GCM land surface schemes to understand their responses to climate change. J Climate 13: 3066-3079. 
Grippa M, Mognard NM, Letoan T, Josberger EG (2004) Siberia snow depth climatology from SSM/I data using a combined dynamic and static algorithm. Rem Sens Environm 93: 30-41.

Gusev YM, Nasonova ON (2003) The simulation of heat and water exchange in the boreal spruce forest by the land-surface model SWAP. J Hydrol 280: 162-191.

Habets F, Saulnier GM (2001) Subgrid runoff parameterization. Phys Chem Earth 26: 455-459.

Habets F, Noilhan J, Golaz C, Goutorbe JP, Lacarrère P, Leblois E, Ledoux E, Martin E, Ottlé C, Vidal-madjar D (1999a) The ISBA surface scheme in a macroscale hydrological model applied to the HAPEX-MOBILHY area. Part I: Model and database. J Hydrol 217: 75-96.

Habets F, Etchevers P, Golaz C, Leblois E, Ledoux E, Martin E, Noilhan J, Ottlé C (1999b) Simulation of the water budget and the river flows of the Rhône basin. J Geophys Res 104: 31 145-31 172 .

Koster DR, Suarez MJ (1992) Modeling the land surface boudary in climate models as a composite of independent vegetation stands. J Geophys Res 97: 2697-2715.

Koster DR, Suarez MJ, Heiser M (2000a) Variability and predictability of precipitation at seasonal to interannual time-scales. J. Hydrometeor 1: $26-46$.

Koster DR, Suarez MJ, Ducharne A, Stieglitz M, Kumar P (2000b) A catchement-based approach to modeling land surface process in a general circulation model: 1. Model structure. J Geophys Res 105: 24 809-24 822.

Koster DR, Dirmeyer PA, Hahmann AN, Ijpelaar R, Tyahla L, Cox P, Suarez MJ (2002) Comparing the degree of land-atmosphere interaction in four atmospheric general circulation model. J. Hydrometeor 3: 363-375.

Lohmann D et al (1998) The Project for Intercomparaison of Land-Surface Parameterization Schemes (PILPS) Phase-2c Red-Arkansas River Bassin experiment: III. Spatial and temporal analysis of water fluxes. Global Planet Change 19: 161-180.

Mahfouf JF, Manzi AO, Noilhan J, Giordani H, Déqué M (1995) The land surface scheme ISBA within the Météo-France climate ARPEGE. Part I: Implementation and preliminary results. J Climate 8: 2039-2057.

Mahfouf JF, Noilhan J (1996) Inclusion of gravitational drainage in a land surface scheme based on the force-restore method. J Appl Meteor 35: 987-992. 
Manabe S (1969) Climate and ocean circulation 1. The atmoosphéric circulation and the hydrology of the earth's surface. Mon Wea Rev 97: 739-805.

Masson V, Champeaux JL, Chauvin F, Mériguet C, Lacaze R (2003) A global database of land surface parameters at $1 \mathrm{~km}$ resolution for use in meteorological and climate models. J Climate 16:

1261-1282.

\section{[http://www.cnrm.meteo.fr/gmme/PROJETS/ECOCLIMAP/page_ecoclimap.htm]}

Nash JE, Sutcliffe JV (1970), River flow forecasting through conceptual models, 1, A discussion of principales. J Hydro 10: 282-290.

Ngo-Duc T, Polcher J, Laval K (2005) A 53-year forcing data set for land surface models. J Geophys Res 110, D06116, doi:10.1029/2004JD005434.

Noilhan J, Planton S (1989) A simple parameterization of land surface processes for meteorological models. Mon Wea Rev 117: 536-549.

Oki T, Sud YC (1998) Design of Total Runoff Integrating Pathways (TRIP). A global river chanel network. Earth Interaction 2: 1-36. [http://EarthInteractions.org/].

Oki T, Nishimura T, Dirmeyer P (1999) Assessment of annual runoff from land surface models using Total Runoff Integrating Pathways (TRIP). J Meteor Soc Japan 77: 235-255.

Peters-Lidard CD, Zion MS, Wood EF (1997) A soil-vegetation-atmosphere transfer scheme for modeling spatially variable water and energy balance processes. J Geophys Res 102: 4303-4324.

Prigent C, Matthews E, Aires F, Rossow WB (2001) Remote sensing of global wetland dynamics with multiple satellite data sets. Geo Res Let 24: 4631-4634.

Robock A, Vinnikov KY, Srinivasan G, Entin JK, Hollinger SE, Speranskaya NA, Liu S, Namkhai A (2000) The Global Soil Moisture Data Bank. Bull Amer Meteorol Soc 81: 1281-1299.

Sivapalan M, Beven KJ, Wood EF (1987) On hydrologic similarity: 2. A scaled model of storm runoff production. Water Resour Res 23: 2266-2278.

Vérant S, Laval K, Polcher J, De Castro M (2004) Sensitivity of the continental hydrological cycle to the spatial resolution over the Iberian peninsulia. J Hydrometeor 5: 267-285.

Warrach K, Stieglitz M, Mengelkamp HT, Raschke E (2002) Advantages of topographically controled Runoff simulation in a Soil-Vegetation-Atmosphere Transfer model. J Hydrometeor 3: 131-148. 
Wigneron JP, Calvet JC, Pellarin T, Van de Griend A, Berger M, Ferrazzoli P (2003) Retrieving near-surface soil moisture from microwave radiometric observations: current status and future plans, Remote Sens Environ 85: 489-506.

Wood EF, DP Lettenmaier, Zartarian VG (1992) A land-surface hydrology parameterization with subgrid variability for general circulation models. J Geophys Res 97: 2717-2728.

Zhao RJ (1977) The Xinanjiang model applied in China. J. Hydrol. 134: 317-381.

Zhao M, Dirmeyer PA (2003) Production and analysis of GSWP-2 Near-Surface Meteorology Data Sets. COLA technical report 159, Center for Ocean-Land-Atmosphere studies, Calverton, US, 36 pp, [http://grads.iges.org/gswp/] 


\section{Figure Captions}

Fig. 1. Schematic representation of the ISBA-TRIP hydrologic modelling system. The ISBA land surface model has a three-layer soil hydrology: the root zone layer overlaps the surface layer whereas the deep-soil reservoir extends from the base of the root zone to the base of the modelled soil column. The two uppermost layers include soil freezing. ISBA takes into account infiltration, soil water transport, surface runoff, deep drainage, bare soil evaporation and soil ice sublimation. The treatment of vegetation includes plants' transpiration, direct evaporation from wet leaves and dripping from the interception reservoir. Snow mass evolves as a function of solid precipitation, snow sublimation and snow melt. TRIP is a simple linear river routing model that is used to convert the total runoff produced by ISBA into river discharges over large rivers (like the Amazons shown in the right panel) at a $1^{\circ}$ by $1^{\circ}$ horizontal resolution.

Fig. 2. Spatial distribution of the drainage areas at each gauging stations used for the discharges validation. Basin names are given in Table 2.

Fig. 3. Comparison between the $10-\mathrm{yr}$ mean runoff ratio simulated by each version of ISBA over the validation period (1986/1995). The runoff ratio, $R$, is defined as the ratio of total runoff (surface runoff + drainage) to total precipitation expressed in $\%$.

Fig. 4. Mean annual cycle (left) and 10-yr timeseries of monthly anomalies (right) of simulated and observed discharges over the Mississippi, the Rio-Amazonas, and the Ob river basins. Note that monthly efficiencies (Eff) shown in left panels are calculated over the whole discharge observation period given in Table 2. The ratio between simulated and observed annual mean discharges $\left(\overline{Q_{\text {sim }}} / \overline{Q_{\text {obs }}}\right)$ and the square correlation $\left(r^{2}\right)$ between simulated and observed monthly anomalies are also shown. 
Fig. 5. Global comparison of the discharge scores obtained in each experiment. The distribution of the mean annual ratio (a) and the cumulative efficiency distribution (b) are shown. Reasonable scores are between 0.9 and 1.1 for the annual ratio, and above 0.5 for the efficiency criterion.

Fig. 6. Spatial distributions of efficiency: comparison between each version of ISBA.

Fig. 7. Mean annual cycle of simulated and observed discharges over the Mississippi, The Danube, the Rio-Amazonas, the Ob, the Parana and the Niger river basins. Notations are the same as in Fig. 4.

Fig. 8. Cumulative efficiency distribution of monthly river discharges simulated by each land surface model given in Table 1. The original version ( $d t 92)$ and the new sub-grid hydrology $(I S B A-S G H)$ of the ISBA model are shown in black and red respectively.

Fig. 9. Spatial distributions of efficiency simulated by each LSM.

Fig. 10. Comparison between simulated and observed mean annual cycles of river discharges (left) and snow cover extent (right) over the Ob and Mackenzie river basins. Notations are the same as in Fig. 4 and 7. Note that the simulation named ISBA-SGH' (red dashed-dotted lines) uses a more sophisticated snow scheme than in the ISBA-SGH simulation. More details are given in section 5 . 


\section{Table Captions}

TABLE 1. Land surface models used for the multi-model comparison. The model structure provides the total number of hydrological (W) and temperature (T) soil layers, as well as the maximum number of snow layers $(\mathrm{S})$. For the representation of the Dunne runoff, three LSMs use a TOPMODEL (TOP) approach while NOAH uses a probability density function $(p d f)$ of total soil moisture $(w)$. For the Horton runoff, ISBA-SGH and SSiB use an exponential distribution of precipitation $(P)$, while SWAP uses a $p d f$ of $k_{s a t}$. In ISBA, two maximum infiltration capacity functions related to a frozen $\left(I_{f}\right)$ or an unfrozen $\left(I_{u n f}\right)$ soil also are used. Others, except NOAH, calculate the Horton runoff only as the difference between through-fall $\left(P_{g}\right)$ and $k_{s a t}$. For the representation of land surface characteristics (Land surface column), Tiles corresponds to the use of a patches approach, Surf-Tiles to the use of a cover tile approach overlying a single soil column, Dominant to the use of the dominant land surface type over the grid cell and Effective to the use of an aggregation parameter method which determines the average values within the grid box.

\begin{tabular}{|c|c|c|c|c|c|c|c|}
\hline$L S M$ & Institutes & Nation & $\begin{array}{c}\text { Model } \\
\text { structure }\end{array}$ & Dunne & Horton & Land surface & Most recent references \\
\hline ISBA-SGH & Météo-France & France & $3 \mathrm{~W} 2 \mathrm{~T} 1 \mathrm{~S}$ & TOP & $p d f\left(P, I_{f}, I_{u n f}\right)$ & Tiles & Decharme and Douville (2006a) \\
\hline MOSES & Met office & UK & $4 \mathrm{~W} 4 \mathrm{~T} 1 \mathrm{~S}$ & TOP & $P_{g}-k_{s a t}$ & Surf-Tiles & $\begin{array}{c}\text { Gedney and Cox (2003), } \\
\text { Essery and al. (2003) }\end{array}$ \\
\hline NOAH & NOAA/NCEP/EMC & USA & $4 \mathrm{~W} 4 \mathrm{~T} 1 \mathrm{~S}$ & $p d f(w)$ & no & Dominant & Ek. et al. (2003) \\
\hline NSIPP & NASA/GSFC/GMAO & USA & $3 \mathrm{~W} 6 \mathrm{~T} 3 \mathrm{~S}$ & TOP & $P_{g}-k_{s a t}$ & Dominant & $\begin{array}{l}\text { Koster et al. (2000b), } \\
\text { Ducharne et al. (2000) }\end{array}$ \\
\hline SSiB & IGES/COLA & USA & $6 \mathrm{~W} 6 \mathrm{~T} 1 \mathrm{~S}$ & no & $p d f(P)$ & Effective & Dirmeyer and Zeng (1999) \\
\hline SWAP & RAS/IWP & Russia & $2 \mathrm{~W} 1 \mathrm{~T} 1 \mathrm{~S}$ & no & $p d f\left(k_{s a t}\right)$ & Effective & Gusev and Nasonova (2003) \\
\hline
\end{tabular}


TABLE 2. River basins used for the comparison between simulated and observed discharges. The number of gauging stations for each basin $(N S)$ is given. The name, drainage area (Area in $\mathrm{km}^{2}$ ), localizations (longitude, Lon, and latitude, Lat), and the observation period of each station are also shown.

\begin{tabular}{|c|c|c|c|c|c|c|}
\hline Basins & $N S$ & Downstream station & $\operatorname{Area}\left(\mathrm{km}^{2}\right)$ & Lon & Lat & Period \\
\hline Rio Amazonas & 12 & Obidos & 4758000 & -55.5 & -2.5 & $86-95$ \\
\hline Congo & 1 & Brazzaville & 3649000 & 15.5 & -4.5 & $86-95$ \\
\hline Mississippi & 8 & Vicksburg & 3011000 & -91.5 & 32.5 & $86-95$ \\
\hline $\mathbf{O b}$ & 5 & Salekhard & 2902000 & 66.5 & 66.5 & $86-95$ \\
\hline Parana & 3 & Timbues & 2596000 & -60.5 & -32.5 & $86-94$ \\
\hline Yenisei & 2 & Ygarka & 2502000 & 86.5 & 67.5 & $86-95$ \\
\hline Lena & 2 & Kusur & 2310000 & 127.5 & 70.5 & $86-95$ \\
\hline Mackenzie & 8 & Mackenzie & 1736000 & -133.5 & 67.5 & $86-95$ \\
\hline Amur & 1 & Komsomolsk & 1772000 & 137.5 & 50.5 & $86-90$ \\
\hline Volga & 1 & Volvograd & 1326000 & 44.5 & 48.5 & $86-90$ \\
\hline Ganges & 1 & Harding Bridge & 970000 & 88.5 & 24.5 & $86-92$ \\
\hline Yukon & 2 & Pilot station & 826000 & -162.5 & 61.5 & $86-95$ \\
\hline Orinoco & 1 & Puentes Angostura & 820000 & -63.5 & 8.5 & $86-90$ \\
\hline Niger & 4 & Niamey & 799000 & 2.5 & 13.5 & $86-90$ \\
\hline Danube & 5 & Ceatal Izmail & 797000 & 28.5 & 45.5 & $86-90$ \\
\hline Columbia & 1 & The Dalles & 634000 & -121.5 & 45.5 & $86-95$ \\
\hline Chari & 1 & Ndjamena & 558000 & 15.5 & 11.5 & $86-91$ \\
\hline Kolyma & 1 & Kolymskoye & 536000 & 158.5 & 68.5 & $86-95$ \\
\hline Brahmaputra & 1 & Bahadurabad & 519000 & 89.5 & 25.5 & $86-92$ \\
\hline Soa Francisco & 1 & Juazeiro & 488000 & -40.5 & -9.5 & $86-94$ \\
\hline Mékong & 5 & Mukdahan & 405000 & 104.5 & 16.5 & $86-93$ \\
\hline Severnaya Dvina & 1 & Ust Pinega & 364000 & 41.5 & 64.5 & $86-95$ \\
\hline Pechora & 2 & Oksino & 298000 & 52.5 & 67.5 & $86-95$ \\
\hline Indigirka & 1 & Vorontsovo & 277000 & 147.5 & 69.5 & $86-94$ \\
\hline Sénégal & 1 & Kayes & 239000 & -12.5 & 14.5 & $86-90$ \\
\hline Yana & 1 & Ubileynaya & 228000 & 136.5 & 70.5 & $86-94$ \\
\hline Fraser river & 2 & Hope & 211000 & -121.5 & 49.5 & $86-95$ \\
\hline Wisla & 1 & Tczew & 194000 & 18.5 & 53.5 & $86-94$ \\
\hline Rhin & 1 & Rees & 146000 & 6.5 & 51.5 & $86-95$ \\
\hline Albany river & 1 & Near Hat Island & 140000 & -83.5 & 51.5 & $86-95$ \\
\hline Burdekin & 1 & Clare & 126000 & 147.5 & -20.5 & $86-94$ \\
\hline Colorado & 1 & Wharton & 105000 & -96.5 & 29.5 & $86-95$ \\
\hline Odra & 1 & Gozdowice & 100000 & 14.5 & 52.5 & $86-94$ \\
\hline
\end{tabular}



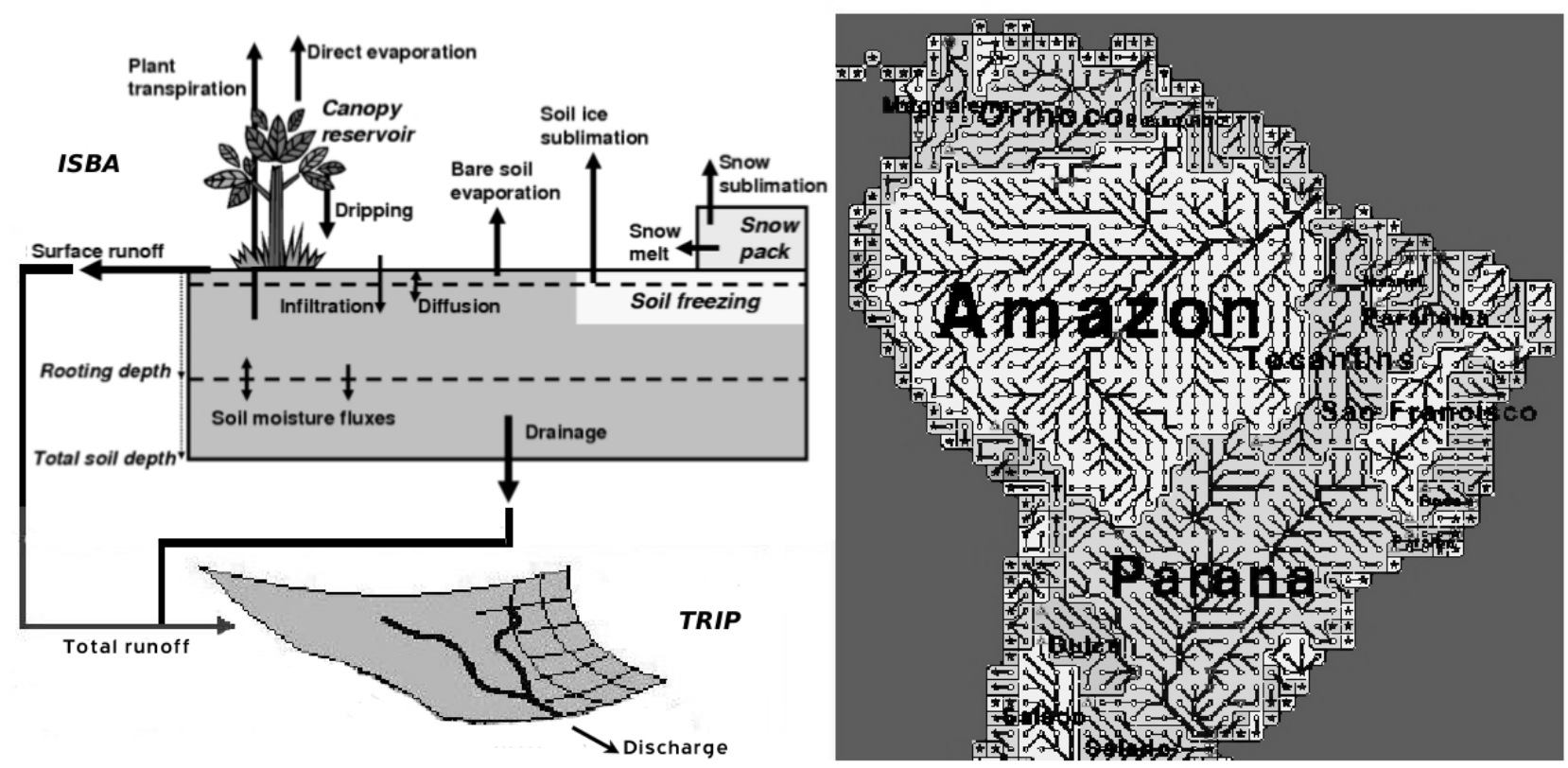

Fig. 1 


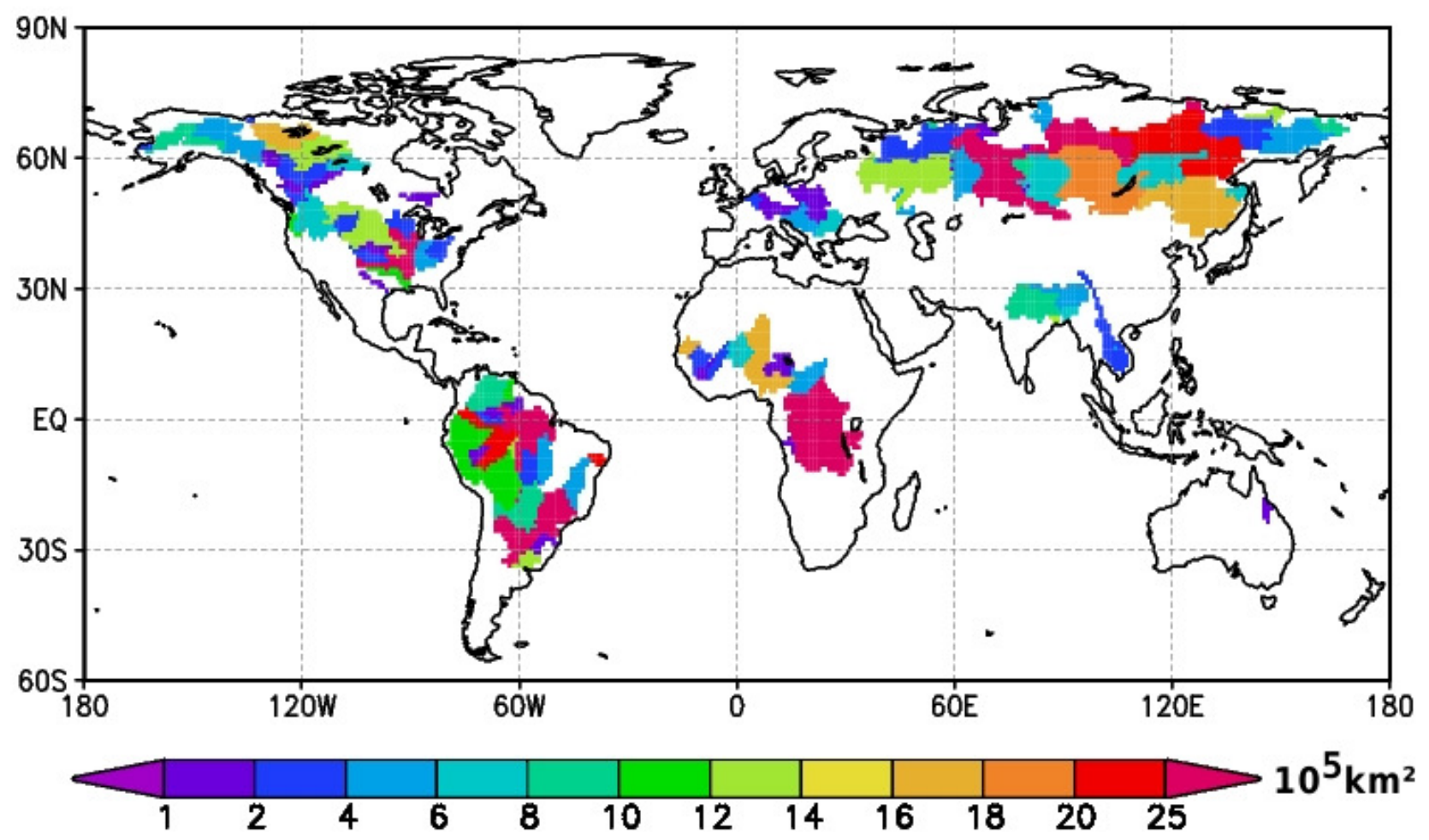

Fig. 2 

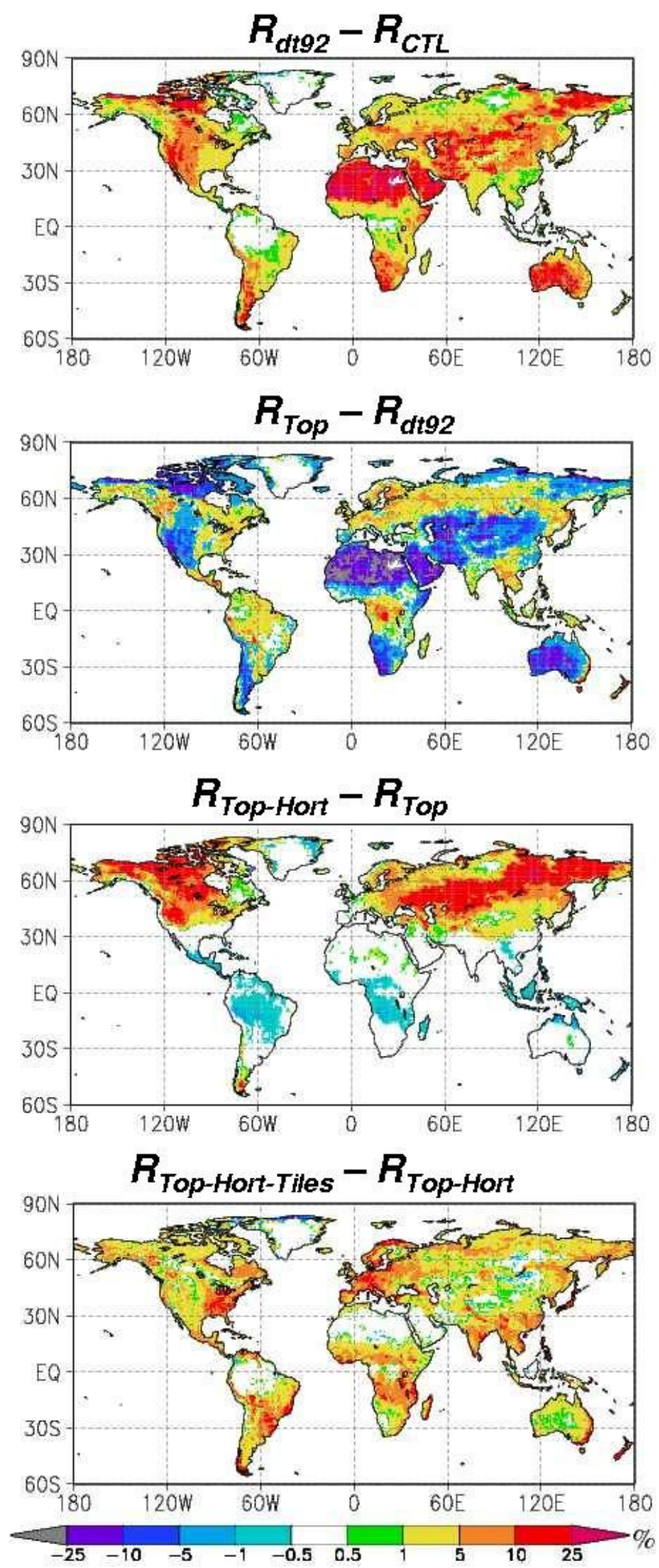

Fig. 3 

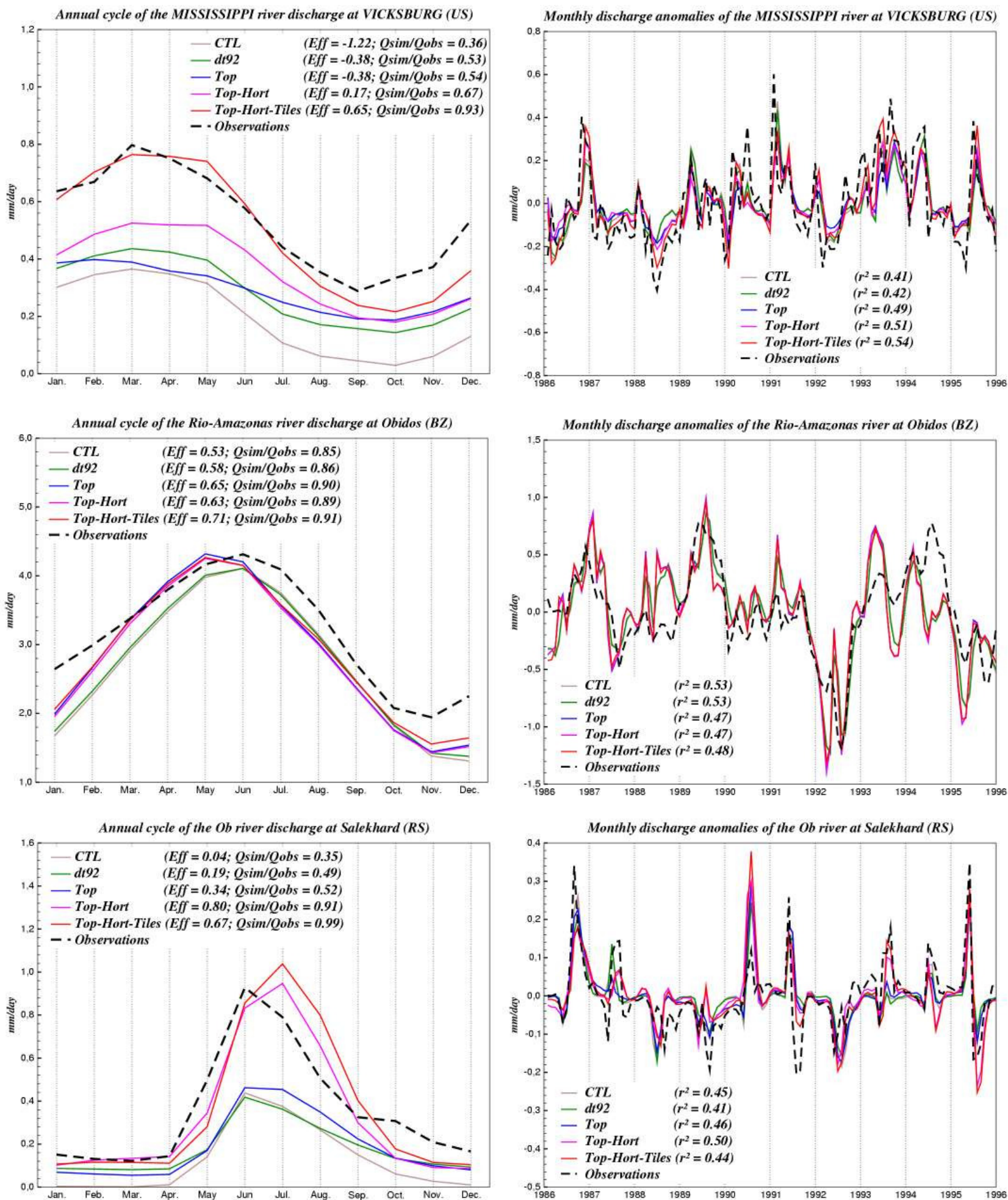

Fig. 4 

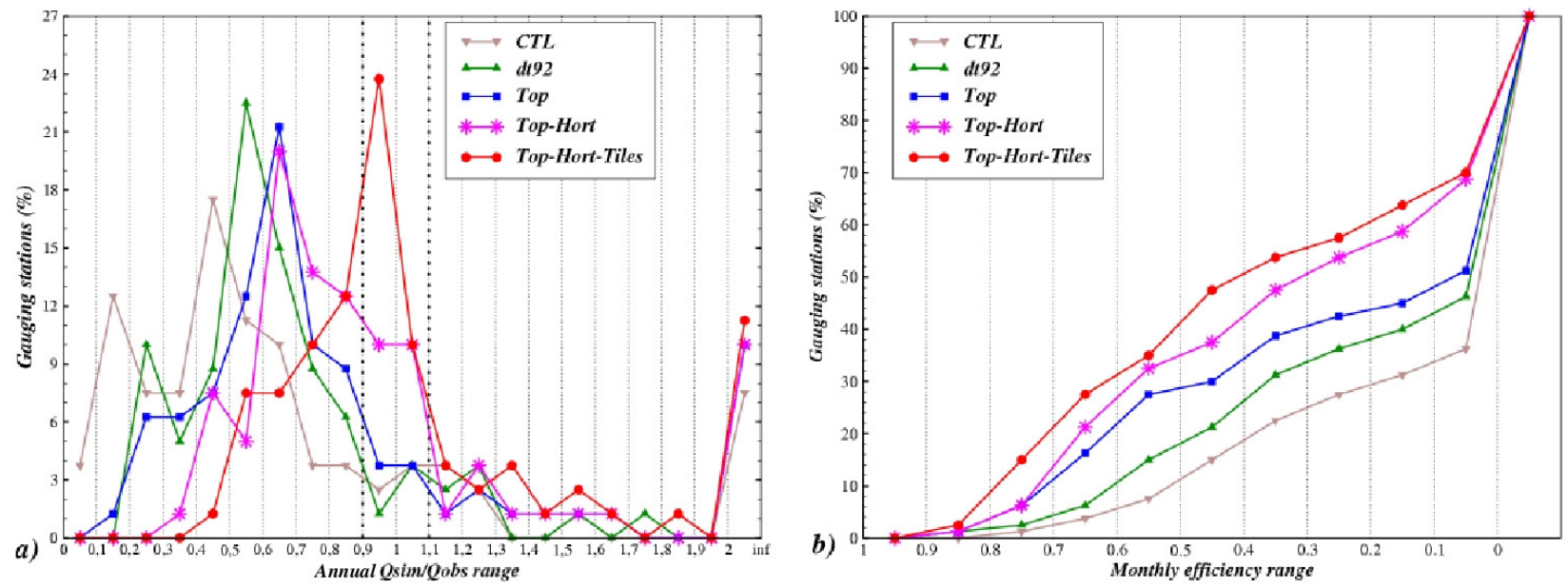

Fig. 5 

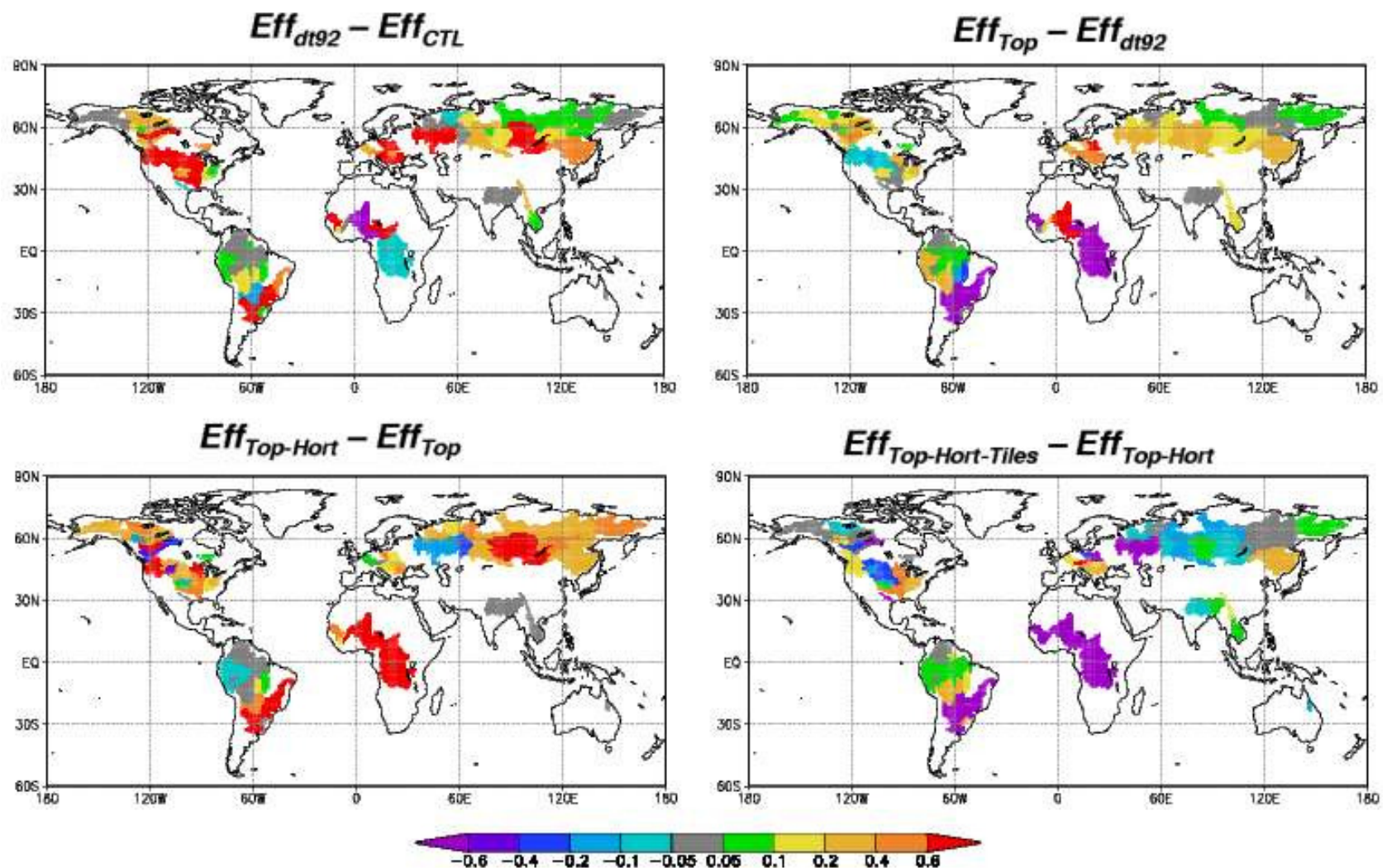

Fig. 6 
Annual cycle of the MISSISSIPPI river discharge at VICKSBURG (US)
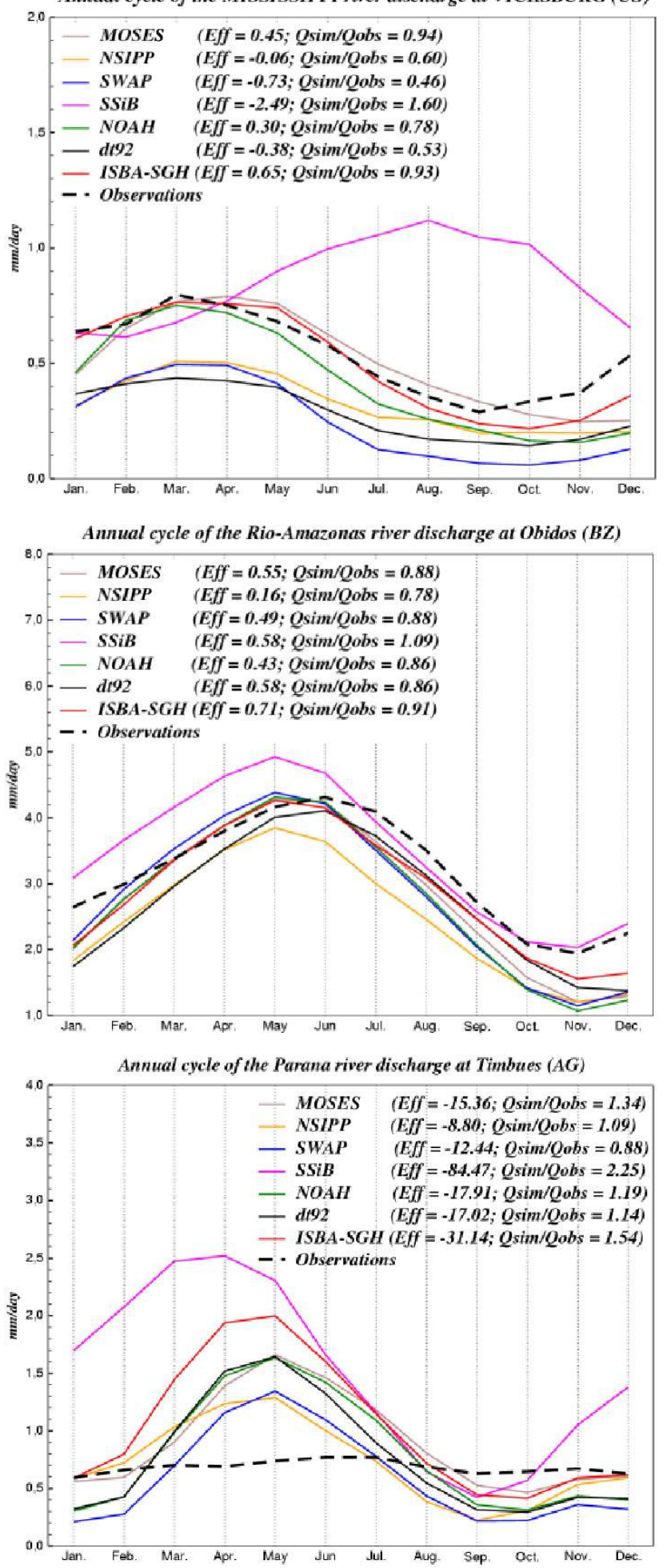

Annual cycle of the DANUBE river discharge at CEATAL-IZMAIL (RO)
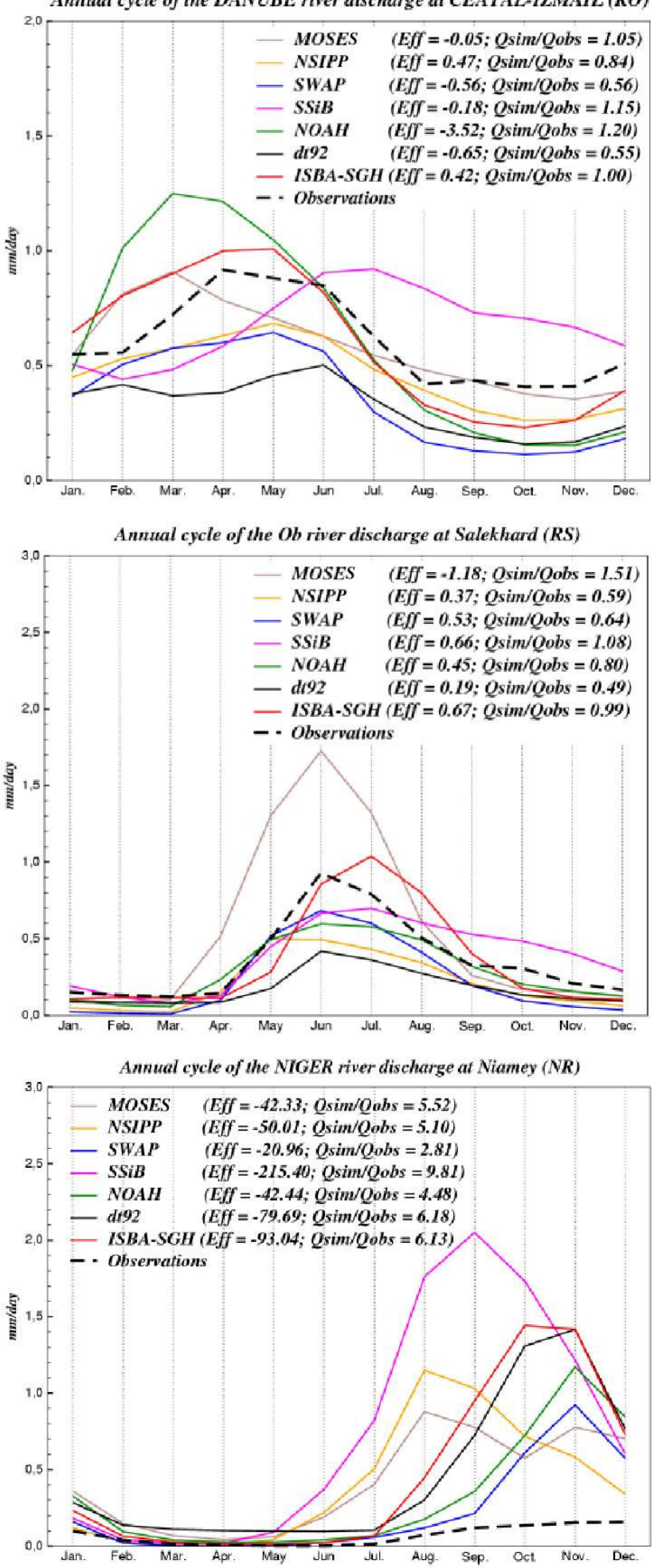

Fig. 7 


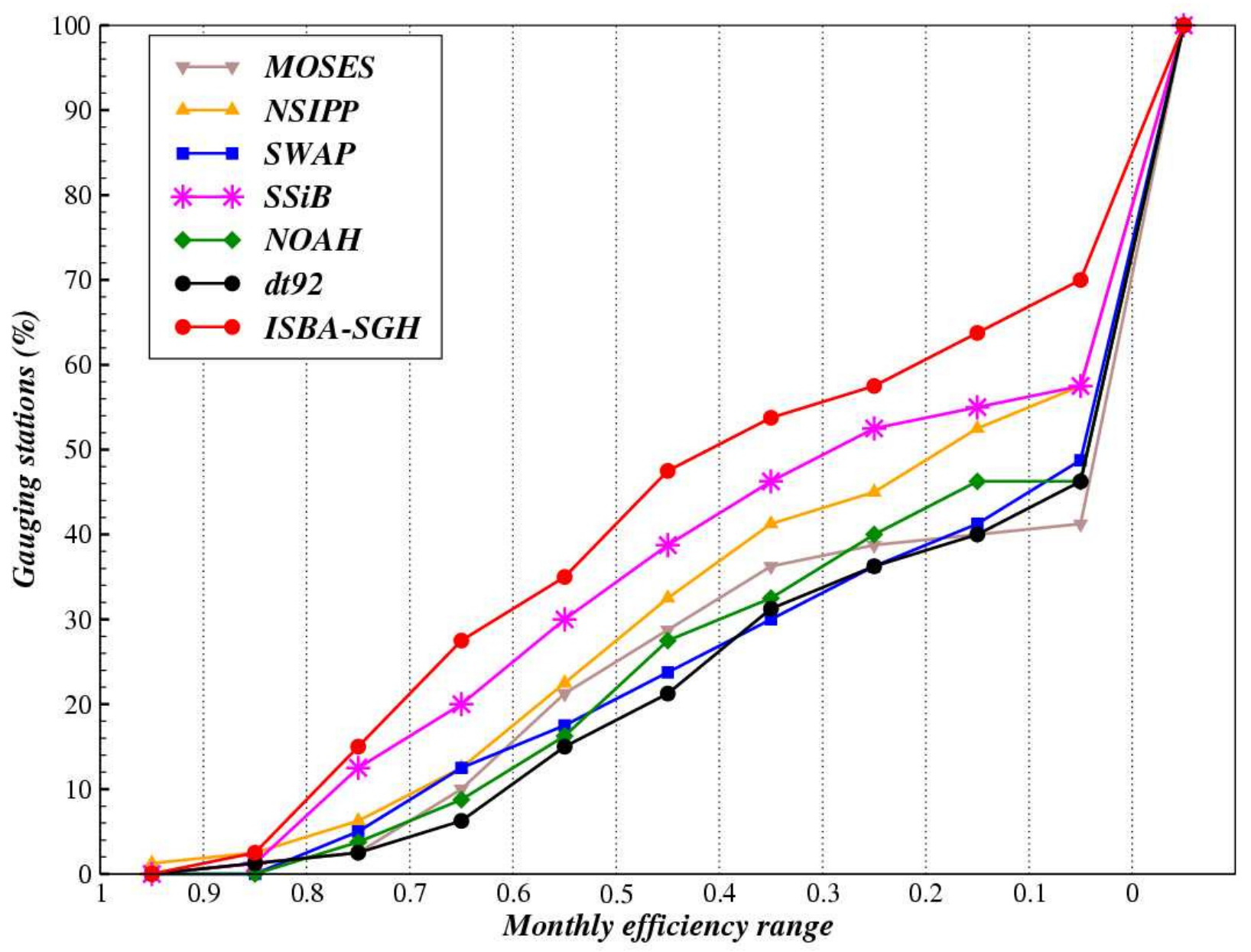

Fig. 8 

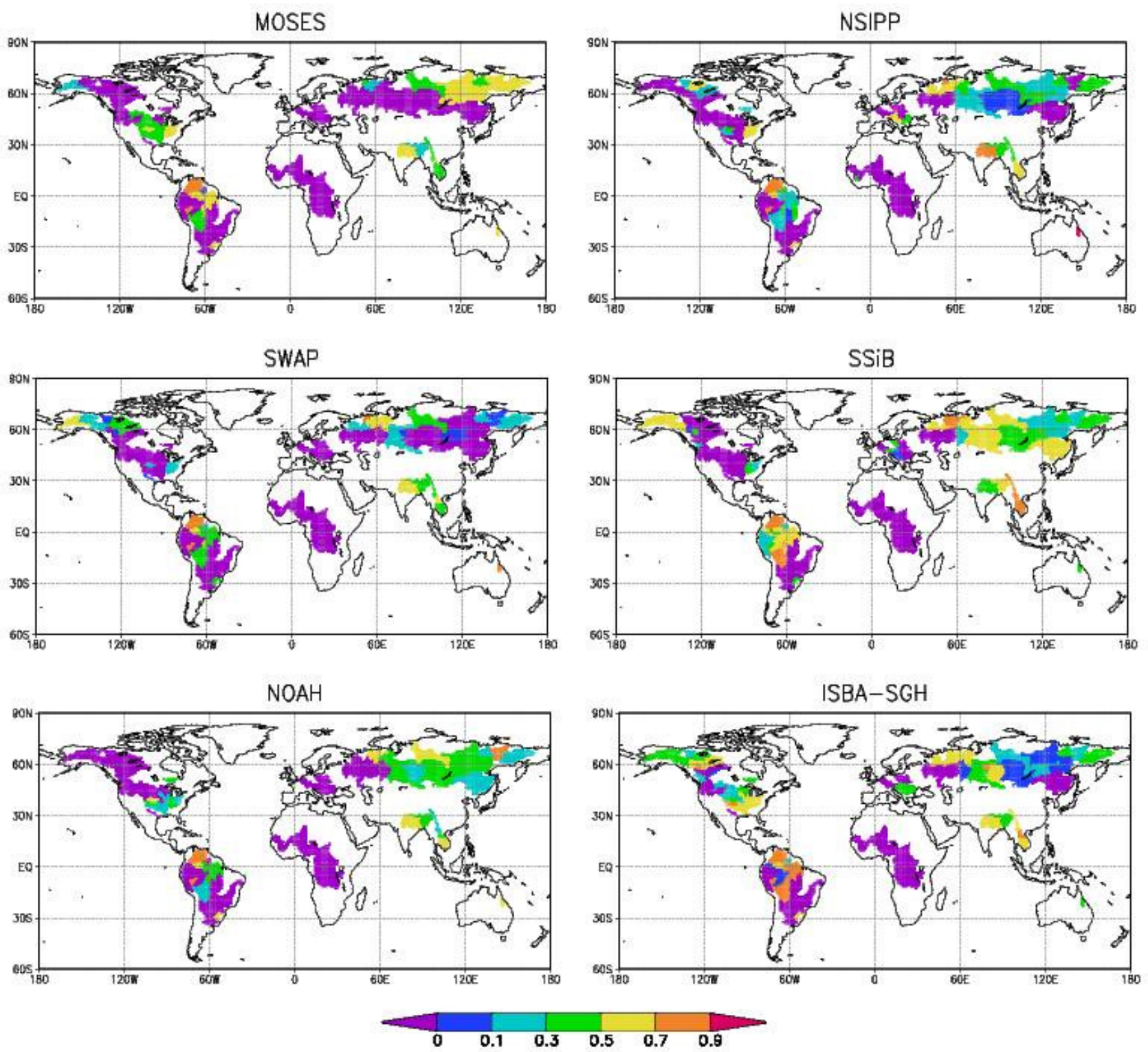

Fig. 9 

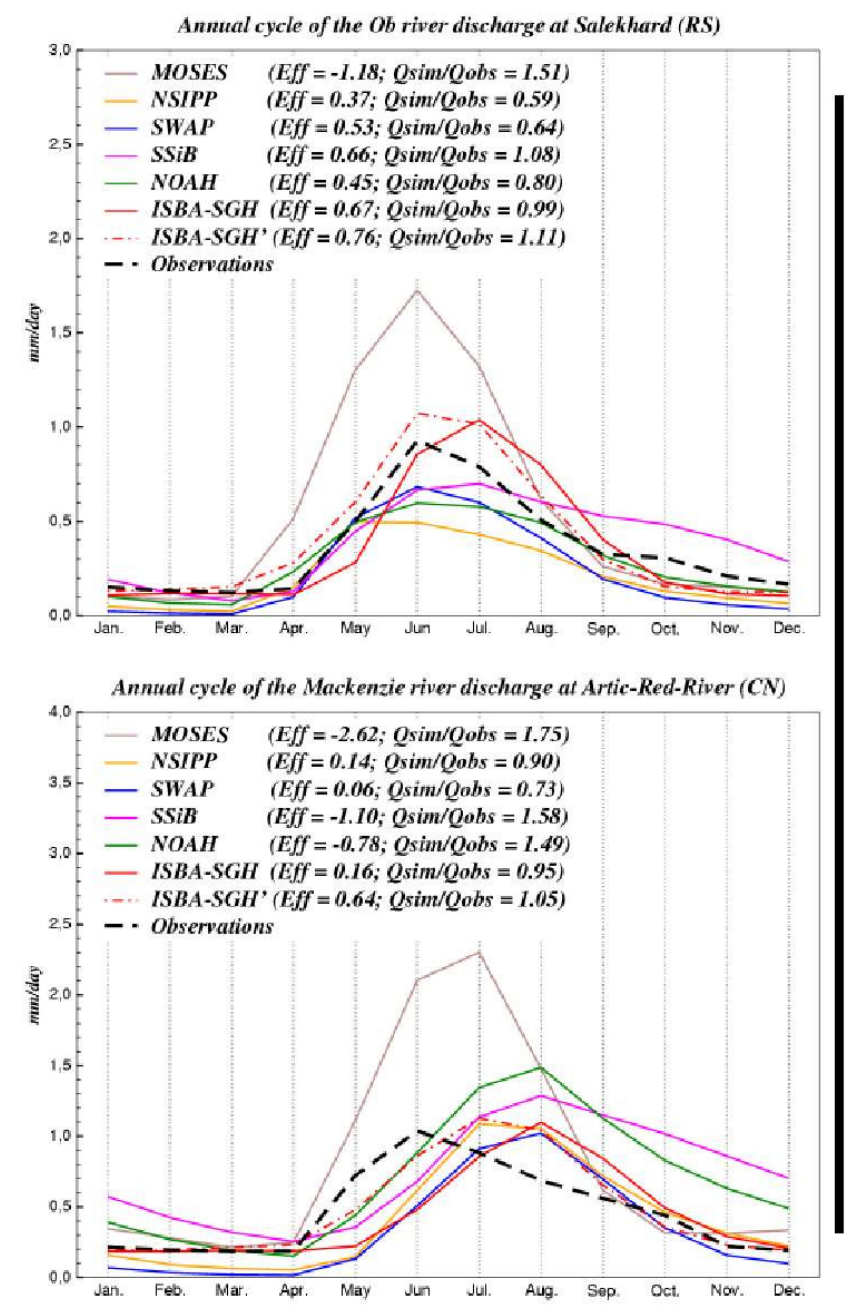
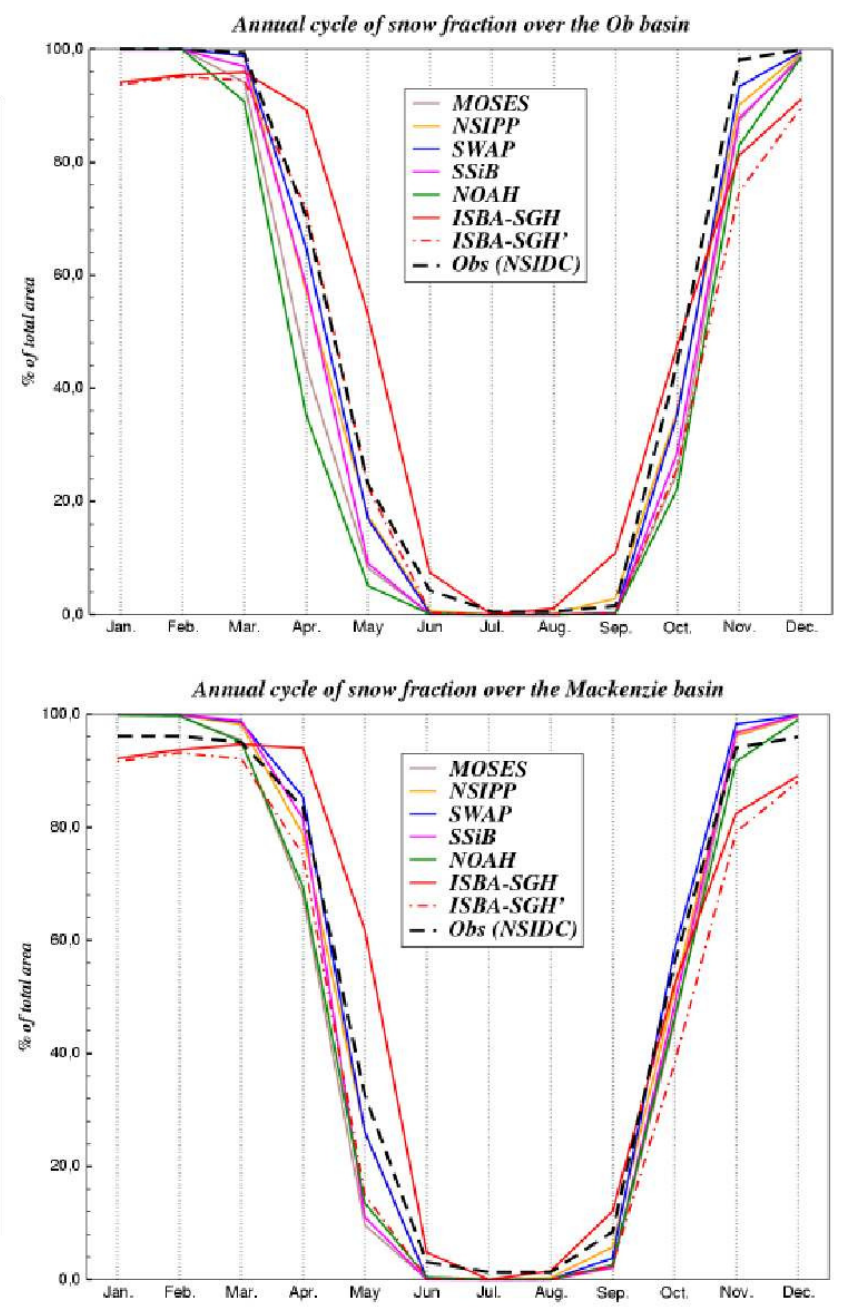

Fig. 10 